\title{
Rekordszinten az EU támogatottsága az EP-választás után
}

36 éves csúcson áll az Európai Unióval kapcsolatos elégedettség a tagállamok lakossága körében - adta hírül a Kantar Hoffmann közvélemény-kutató által az Európai Parlament megbízásából készített legfrissebb Eurobarometer-felmérés. ${ }^{1}$ A 2019. május 26-i EP-választást követő egy hónapon belül 28 tagállamban, közel 28 ezer válaszadó részvételével végzett közvélemény-kutatás kifejezetten az EP-választáson való részvétel motivációit vizsgálta.

Az eredmények nyomán több tekintetben fontos - pozitív - jelzéseket emelhetünk ki: a válaszadók 68\%-a vélekedett úgy, hogy az EU-tagság előnyös volt országa számára. Néhány példa: Litvánia - 91\%, Írország - 89\%, Észtország - 87\%, Lengyelország - 86\%, Magyarország - 84\%, EU-átlag - 68\%, Egyesült Királyság - 59\%, Olaszország - 57\%. E néhány adatból is látható, hogy a gazdaságilag sikeres, felzárkózó, modernizálódó országok lakosai általánosságban elégedettek az uniós tagsággal. Az elmúlt egy évtizedben először 2017 októbere óta relatív többségben (48\%) vannak azok, akik úgy érzik, számít a véleményük az EU-n belül, és ez 2018 júniusára abszolút többséggé is vált (56\%). Néhány példa: Svédország - 86\%, Dánia - 81\%, Hollandia - 76\%, Németország - 75\%, EU-átlag - 56\%, Magyarország - 55\%, Lettország, Görögország, Észtország - 30\%.

A véleményformálás és az uniós politikai folyamatok befolyásolási szándéka az EPválasztás kapcsán is jól látható volt: 1994 óta elöször nőtt a részvételi arány, egyben a legmagasabb arányban $(50,6 \%)$ vettek részt az uniós állampolgárok a választáson. A legmagasabb részvételi arányt Belgiumban (88\%), Luxemburgban (84\%) és Máltán (73\%) láthattuk, a legalacsonyabbat Szlovéniában (29\%), Csehországban (29\%) és Szlovákiában (23\%). Azonban ennél többet mond, hogy egyes tagállamokban jelentősen nőtt a szavazók száma: Spanyolországban $(+17 \%)$, Németországban $(+13 \%)$, Ausztriában $(+15 \%)$, Romániában (+19\%), Lengyelországban (+22\%), Magyarországon pedig 14\%-kal - amiből arra következtethetünk, hogy egyre több választó kívánja hallatni hangját európai szinten is.

Ugyancsak jelzésértékű, hogy a legnagyobb arányban a választói csoportok közül a fiatalok részvétele bővült: a 18-24 évesek közül 50\%-kal többen mentek el szavazni, mint 2014-ben, de a 25-39 éves korosztályban is 12\%-kal több szavazó járult az urnákhoz - azaz a fiatal korosztályok politikai érdeklődése és véleményformálási szándéka erősödik.

A választók motivációja szempontjából a legfontosabb érvek között szerepelt, hogy a részvétel állampolgársági kötelezettség (52\%), hogy ki kívánták nyilvánítani támogatásukat az EU felé (25\%), és hogy ezáltal változtatni képesek (18\%), azaz szavazatuk számít.

The 2019 elections. A pro-European - and young - electorate with clear expectations. First results of the European Parliament post-electoral survey, [online], 2019. 07. 12. Forrás: Special Eurobarometer 915. Kantar - European Parliament [2019. 07. 20.] 
Ugyanakkor a franciák, görögök és britek jelentős arányban (mindegyik esetben 22\%) azért szavaztak, hogy elégedetlenségüknek adjanak hangot (az uniós átlag 12\%, Magyarországon $17 \%)$.

Az EU számára legfontosabb problémák között a gazdasági növekedés fenntartása (44\%), az éghajlatváltozás (37\%), az emberi jogok és a demokrácia propagálása (37\%) és „az EU jövőbeni müködési modellje” (36\%) szerepelt, de hangsúlyos témaként jelent meg a bevándorlás (34\%), a terrorizmus (26\%), valamint a biztonság- és védelempolitika $(25 \%)$ is. 